\title{
Leiding geven aan veranderingen
}

\author{
Thalita G. M. Smit-Cornelder
}

Published online: 21 August 2020

(C) Bohn Stafleu van Loghum is een imprint van Springer Media B.V., onderdeel van Springer Nature 2020

Samenvatting Er wordt te vaak gemakkelijk gedacht over het doorvoeren van een verandering in een praktijk die verder goed draait. In de gemiddelde praktijk leiden vooral ontoereikende communicatie en gebrekkig leiderschap, in combinatie met het ontbreken van een duidelijke visie tot problemen. Wat komt er eigenlijk allemaal kijken bij een veranderingsproces? Op die vraag geeft dit artikel praktische antwoorden waarmee iedereen die zich voor zo'n proces gesteld ziet, in ieder geval op weg geholpen wordt.

Trefwoorden leiding geven · management

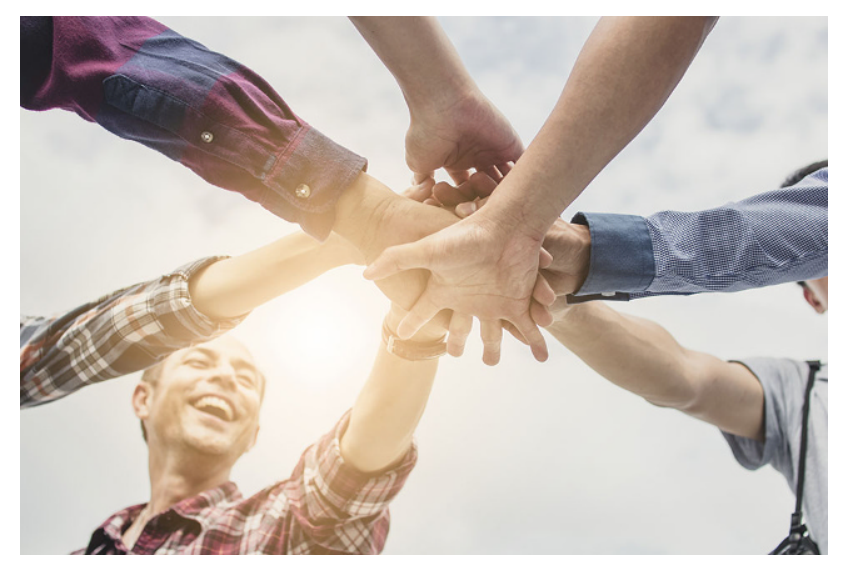

\section{Inleiding}

Veranderen is de enige constante hoor je wel eens zeggen. En dat is waar. Of het nu om kleine dingen gaat, zoals een tuinfeestje dat je gepland hebt in de zomer,

T. G. M. Smit-Cornelder ( $\bowtie)$

Smit \& Cornelder Bedrijfstrainingen, Eindhoven, Nederland thalita@smitencornelder.nl maar door een fikse regenbui om aanpassingen vraagt, of om COVID-19 dat direct om een andere werkwijze vraagt. Veranderen is lastig en vraagt tijd en inzicht. Bij een urgente situatie of crisis zullen de aanpassingen vooral gericht zijn op het besparen van kosten en het verbeteren van efficiency. Hoe dan ook moet er een bepaalde noodzaak zijn om te veranderen.

\section{Integraal verandermanagement}

Veranderingen doorvoeren in een praktijk waar met meerdere mensen wordt samengewerkt, is een hele opgave. Waarom is veranderen lastig? Veranderingen brengen onzekerheden met zich mee en van nature gaat de mens onzekerheden liever uit de weg. De mens houdt graag vast aan het bekende. Veranderen gaat in veel gevallen gepaard met weerstand. We doen het pas als de nood zo hoog is dat we geen andere keuze meer hebben. Daarnaast moet er een duidelijk veranderdoel zijn. Toch is het mogelijk om veranderingen door te voeren en iedereen in de praktijk mee te krijgen, maar het vraagt absoluut om leiderschap.

Bij verandertrajecten krijg je te maken met de technische kant van de praktijk, zoals visie, strategie en structuren, en met de menselijke kant, zoals leiderschap en communicatie. Krijg je je medewerkers niet mee met de verandering, dan ligt mislukking op de loer.

Er zijn tal van redenen om te veranderen; mogelijk vraagt COVID-19 nu om een nieuwe kijk op jouw praktijk en werkwijze of groei je zo hard dat er een nieuwe werkwijze nodig is. Om veranderingen door te voeren, doorloop je een aantal aandachtsgebieden die allemaal met elkaar samenhangen. Bij elk aandachtsgebied horen een aantal stappen die doorlopen moeten worden. 
De aandachtsgebieden zijn:

1. de diagnose, analyse van de context van de praktijk;

2. visie en herontwerp, de verandering zelf;

3. gedragsmodellen, dynamiek bij veranderen;

4. aansturen op de menselijke kant.

\section{Diagnose en analyse van de context}

De eerste is stap is dat je een goede analyse maakt van jouw praktijk. Wat speelt er binnen de praktijk, wat is de geschiedenis van de praktijk, welke ongeschreven regels gelden er, en wat zijn kenmerkende eigenschappen van de medewerkers? Deze basis is belangrijk, omdat dit de 'organisatiecondities' zijn waaronder de praktijk moet veranderen. Waarom is het noodzakelijk dat de praktijk verandert? Hoe complex zal deze verandering zijn? En natuurlijk de vragen 'waar willen we naartoe?' en 'wat willen we bereiken'? Er is een duidelijke visie nodig om veranderingen door te kunnen voeren.

\section{Visie en herontwerp}

Uit de analyse in stap 1 zijn problemen en ontwikkelingen voortgekomen waarop een antwoord moet komen. Dit antwoord is een aanpassing of verandering van de huidige situatie naar de nieuwe, met als einddoel een verbetering voor de praktijk. Je kan dit het herontwerpen van de praktijk noemen.

\section{Gedragsmodellen en dynamiek}

Bij het herontwerpen van de praktijk is het van groot belang om rekening te houden met het gedrag van de medewerkers. Zij willen weten waar ze aan toe zijn, wat de gevolgen zijn en wat de verandering hen oplevert. Tot dit duidelijk is, zullen de medewerkers niet snel geneigd zijn om mee te gaan met het 'herontwerp'. Logisch ook, want die situatie brengt onzekerheden met zich mee en daar kiezen we als mens niet zomaar voor.

De rol van degene die de veranderingen door wil voeren, vraagt om empathie en leiderschap. Je moet je kunnen inleven in de gevoelens van de medewerkers, en onzekerheden en onduidelijkheden wegnemen, terwijl intussen de veranderingen wel doorgevoerd gaan worden.

Er zullen medewerkers zijn die de veranderingen meteen accepteren en er enthousiast mee aan de slag gaan (early adaptors). Andere medewerks willen eerst even de kat uit de boom kijken en dan pas meegaan met de veranderingen (late majority), en je hebt ook medewerkers die de hakken in het zand zetten en geen aanstalten maken om mee te doen (laggards) [1]. Begrip hiervoor vraagt veel inzicht in menselijk gedrag en tegelijkertijd om de juiste communicatietechnieken. Er zullen diverse leiderschapsstijlen ingezet moeten worden, afhankelijk van het moment en de situ- atie. Om een goed herontwerp te maken, zal je eerst moeten bepalen welk doel de praktijk nastreeft.

\section{De menselijke kant}

De gedragspatronen die medewerkers laten zien in reactie op de verandering en de dynamiek die hierbij komt kijken, vereisen een strategie en aanpak die positief genoeg zijn om de verandering daadwerkelijk door te voeren. Er is aandacht nodig voor de technische kant, zoals hiervoor beschreven, maar zonder aandacht voor de menselijke kant zal het vertrouwen en de toewijding onder de medewerken niet groot genoeg zijn om mee te veranderen. Leiderschap, communicatie en inzicht in gedragspatronen, dat is nodig bij veranderprocessen. Blijf tijdens de uitvoer van je verandering oog houden voor zowel de mens als de praktische uitvoering.

\section{Een voorbeeld}

Stel, je hebt een praktijk met tien medewerkers. De eigenaresse is zelf podotherapeut en naast cliënten behandelen, moet ze ook de praktijk aansturen. Alles bij elkaar is het veel werk en vaak komt dat op het weekend aan. Er is een ander pand gekocht met meer ruimte en de verbouwing is daar in volle gang. $\mathrm{Nu}$ is er een collega die heeft aangegeven dat zij zich graag wil ontwikkelen op het gebied van organisatie en aansturing. Gezien de enorme drukte en groei van de praktijk is hulp welkom, maar er zijn ook vraagtekens. De urgentie om de organisatiestructuur te veranderen, komt voort uit de grote groei van de praktijk.

Diagnose en analyse De praktijk bestaat vijftien jaar en is uitgegroeid naar een praktijk met tien medewerkers. De eigenaresse was altijd degene die de beslissingen nam en bij wie de medewerkers met hun vragen konden aankloppen. Ze houdt veel rekening met haar medewerkers, meestal ten koste van zichzelf, en het is nu zelfs zo dat zij vele malen drukker is dan haar medewerkers. Momenteel wordt er een nieuw pand ingericht met meer ruimte en meer behandelkamers en de verhuizing zal over een paar maanden plaatsvinden. Elke vraag van de medewerkers komt bij de eigenaresse terecht.

De nieuwe visie van de eigenaresse is: Wij zijn de meest innovatieve praktijk op het gebied van sportpodotherapie en hebben een zelfstandig team waarin iedereen zich kan en mag ontwikkelen en de medewerkers zich eigenaar van de praktijk voelen.

Visie en herontwerp Er is een hoop om aan te werken. De eigenaresse zal werk uit handen moeten geven, wil ze tijd blijven houden voor het aansturen van de praktijk en voor de verbouwing. De medewerkers moeten zelfstandiger gaan functioneren en er moet duidelijkheid komen over waar zij met hun vragen terechtkunnen. Er moeten nieuwe interne regels 
komen. De meest innovatieve praktijk betekent bijscholen, investeren, acquisitie doen, maar ook twee avonden per week spreekuur en de zaterdagochtend open. Tevens moet er zo efficiënt mogelijk gewerkt gaan worden, want er komen veel uitvoerende taken bij en dat moet ergens opgevangen worden. Het zijn veranderingen die een beroep doen op de betrokkenheid van de medewerkers.

Gedragsmodellen en dynamiek Er komt een herontwerp van de praktijk, met als uitgangspunt dat bij het betrekken van het nieuwe pand de medewerkers weten wat er van hen verwacht wordt. Eerste stap is de visie op papier zetten en dan in gesprek gaan met de medewerkers om hen te betrekken bij de organisatie, de aansturing en de nieuwe visie. Welke werkzaamheden kunnen bij welke werknemers neergelegd worden? Wie is geschikt voor welke taak en/of rol? De nieuwe visie én de nieuwe taken en verantwoordelijkheden moeten door alle werknemers geaccepteerd worden. Zoals de nieuwe openingstijden, de bijkomende taken naast het behandelen etc., maar ook hoe er zo efficiënt mogelijk gewerkt kan worden. Hier komen de technische kant en de menselijke kant samen.

De menselijke kant De op handen zijnde veranderingen gaan door; je moet het alleen in goede banen leiden en dat is een hele opgave. De medewerkers zullen met weerstand en vragen komen en alleen wanneer je duidelijk kan uitleggen wat de reden is van de veranderingen en wat de veranderingen hen opleveren, zullen ze meegaan. Het kan ook zijn dat je uiteindelijk afscheid moet nemen van iemand die zich niet in de veranderingen kan schikken. Empathie en begrip voor de medewerkers is noodzakelijk, terwijl de veranderingen wél doorgevoerd worden. De nieuwe visie geeft richting en is de rode draad bij alle acties en beslissingen. Zorg voor openheid en veiligheid, zodat iedereen zich vrij voelt om zich te uiten. Commu- niceer regelmatig met elkaar om de vorderingen die gemaakt zijn door te spreken en iedereen betrokken te houden bij de veranderingen, zonder af te wijken van het beoogde doel.

\section{Take home messages}

- Er wordt te vaak gemakkelijk gedacht over het doorvoeren van een verandering. In de gemiddelde praktijk leiden vooral ontoereikende communicatie en gebrekkig leiderschap, in combinatie met het ontbreken van een duidelijke visie tot problemen.

- Het veranderproces neemt te veel tijd in beslag, met als gevolg weerstand en medewerkers die vertrekken. Dit komt mede omdat er te weinig tijd wordt vrijgemaakt voor het doordenken van dit soort trajecten, onder andere omdat het spannend is. Grote veranderingen doorvoeren in de praktijk is een lastige opgave.

- Er wordt enorm veel gevraagd van degene die de veranderingen moeten doorvoeren. Naast de technische aspecten is het menselijk aspect van groot belang voor het meekrijgen van de medewerkers. Er wordt coachend leiderschap verwacht, waarbij het doel van de verandering leidend is, met de visie als rode draad.

- Tijd, geduld en een deadline zijn ook belangrijke aspecten. We werken liever in onze praktijk dan aan onze praktijk. En dit laatste is toch echt belangrijk met het oog op de toekomst.

\section{Literatuur}

1. Rogers E. The diffusion of innovations. 5e druk. New York: TheFree Press; 2003.

Thalita G.M. Smit-Cornelder, ondernemerscoach en leiderschapstrainer 